\title{
Degradation of nucleic acids and nucleotides in several conditions with perspectives of retrieval: A review
}

\author{
José Martínez Reyes ${ }^{1 *}$, Lenin Ejecatl Medina Orozco ${ }^{2}$, Melitón Estrada Jaramillo ${ }^{1}$, \\ Iván Vera Romero ${ }^{1}$, Agustina Ortiz Soriano ${ }^{3}$
}

\footnotetext{
${ }^{1}$ Trajectory of Energy Engineering, University of the Ciénega of Michoacán State, Sahuayo, Méxio

${ }^{2}$ Trajectory of Food Genomics, University of the Ciénega of Michoacán State, Sahuayo, Méxio

${ }^{3}$ Trajectory of Educational Innovation, University of the Ciénega of Michoacán State, Sahuayo, Méxio

Email: ${ }^{\text {jmmreyes@geociencias.unam.mx }}$
}

Received 24 November 2013; revised 25 December 2013; accepted 5 January 2014

Copyright (C 2014 José Martínez Reyes et al. This is an open access article distributed under the Creative Commons Attribution License, which permits unrestricted use, distribution, and reproduction in any medium, provided the original work is properly cited. In accordance of the Creative Commons Attribution License all Copyrights @ 2014 are reserved for SCIRP and the owner of the intellectual property José Martínez Reyes et al. All Copyright (C) 2014 are guarded by law and by SCIRP as a guardian.

\section{ABSTRACT}

Deoxyribonucleic acid (DNA) or oligonucleotides, can be modified in several ways as chemical degradation by electrophilic reaction, attack of radicals, hydrolytic deamination or oxidative damage caused by ionizing radiation. This work discussed these degradation mechanisms, determining the effects on these biomolecules. The actual knowledge about DNA damages only permits partial enzymatic repair treatments.

\section{KEYWORDS}

DNA; Chemical; Degradation

\section{INTRODUCTION}

Biological markers (biomarkers) are complex molecular fossils from biomolecules in living organisms. They are generally resistant to weather, the biodegradation, evaporation and other biological processes. As commonly preserved in rocks, they can be used by geologists, geochemists, archaeologists, evolutionist biologist, etc. for information on organic matter in source rocks, the presence of oil, environmental conditions during sedimentation (diagenetic process), the thermal maturity experienced by the oil and/or rock (catagenetic process), the degree of biodegradation, some aspects of mineralogy of the source rock (lithology), the age of fossils and characterization of biomarkers.

Biological markers can be DNA (DeoxyRibonucleic Acid) or oligonucleotides, which are stretches of DNA molecules of simple fixed-length string.

The continuous advances in DNA sequencing techniques allow faster and complete studies of sequenced
DNA for fields as the evolutionist biology provide indirect evidence on the comparison of DNA sequences from living organisms, of the historical processes that have formed them over long periods of time. The study of DNA from fossils organisms offers a partial way out to this problem, because many technical pitfalls need to be innovated to allow the reconstruction and/or study of the molecules. By example, DNA from fossils can form cross-links among themselves or with other molecules to the passage of time, hindering the use of techniques such as PCR for study [1,2].

Therefore, this work discussed some degradation mechanisms of nucleic acids, oligonucleotides and nucleotides, determining the effects on these biomolecules by agents of degradation and finally exposed the major techniques available for the retrieval of ancient and damaged DNA.

\section{CHEMICAL DEGRADATION OF DNA}

There are some functional groups or chemical structures that can modify the DNA. These molecules possess sufficient reactivity to make changes and break covalent bonds within DNA. Almost all the DNA reactions fall into just two general categories: 1 ) the reaction of a DNA nucleophile with an electrophile or 2) the reaction of a DNA pi bond or c-h bond with a radical [3-6].

\subsection{Electrophilic Degradation Reactions}

Potentially, all of the heterocyclic bases in DNA, could to act as nucleophiles in reaction with electrophiles. as is expected, access to some sites is limited in doublestranded DNA relative to single-stranded DNA [7,8], but, reactions are not completely precluded even at locations 
on Watson-Crick hydrogen bonding surfaces of the bases that reside near the helical axis of the duplex. The factors that determine the atom site selectivity for a given DNAalkylating agent are complex [7-11]. A recent detailed study of alkylation by diazonium ions led to the conclusion that atom site selectivities seen in duplex dna do not reflect intrinsic nucleophilicities of the heteroatoms in the nucleobases. Rather, placement of the nucleobases into the environment of the double helix substantially alters the nucleophilicity of base heteroatoms. factors that alter the nucleophilicities of various heteroatoms in the dna bases, when placed within the context of double helix, include proximity of the polyanionic sugar-phosphate backbone, lower dielectric constants in the dna grooves relative to bulk water, and interaction of the inherent dipoles of the nucleobases with the electrostatic environment of the double helix (e.g., charges of the backbone and neighboring bases) [11].

\subsection{Reactions of Radicals with the Heterocyclic Bases}

Radicals react with bases frequently by addition to the pi bonds in the heterocyclic nucleobases or by hydrogen atom substraction. These reactivity has been extensively studied in the context of hydroxyl radical ( $\mathrm{HO} \bullet$ ), which is generated by radiolysis of water. When DNA is exposed to the hydroxyl radical, approximately $80 \%$ of the reactions occur at the bases [12-14]. Many base damage products arising from the reaction hydroxyl radical with DNA have been characterized [13,15-19]. Radical attack yields nucleobase radical adducts that must undergo either oxidation or reduction to yield a stable final product. The cellular oxidant in these reactions may be molecular oxygen or high-valent transition metal ions (e.g., $\mathrm{Fe}^{3+}$ ), while the reductant may be either thiols, superoxide radical, or low-valent transition metal ions (e.g., $\mathrm{Fe}^{2+}$ ). In many cases, the base remains largely intact and the sequence of chemical events can be readily inferred. In some other cases, more extensive base decomposition occurs.

\subsection{Reactivity in Archaeological Deposits}

Ancient DNA contains only a small fraction of specimens endogenous [20], the reason for this is damage to the DNA that accrues over. Mainly two kinds of modification are likely to affect dna in an archaeological environment. First, hydrolytic reactivity will result in deamination of bases and in depurination and depyrimidination [21]. In second place, oxidative damage, caused by the direct interaction of ionizing radiation with the DNA, as well as mediated by free radicals created from water molecules by ionizing radiation, will result in modified bases [21,22]. Other mechanisms, for example alkylation or uv irradiation, are less likely to affect buried remains. Ancient DNA is degraded to a small average size containing abasic sites and oxidation products of pyrimidines [23]. Gas chromatography/mass spectrometry (GC/ MS) is particularly suited to identify and quantify modifications in DNA [24].

\section{RETRIEVAL OF ANCIENT AND DAMAGED DNA}

The formulation of theories and deductions about the evolution of species are inferred from studies of genetic diversity in contemporary populations. The retrieval of ancient DNA from archaeological remains holds the promise to add a new tool to such studies, with the invention of PCR [25,26], as mentioned ancient DNA contains only a small part of sequences that can be amplified by the polymerase chain reaction (PCR) [20]. The PCR is the main technique to retrieve ancient DNA sequences.

It became possible to study ancient DNA sequences [23]. Contributing mainly to areas as phylogenetic relationships of extinct animals [20,27,28], whereas results in other areas have remained controversial [21,29] or difficult to authenticate. This is the situation, for example, for the retrieval of DNA sequences from ancient human remains [30].

Biochemical methods can identify ancient DNA alterations and inadequate sequencing [31].

There are evidence that inter-strand crosslinks, prevent amplification, may accrue more quickly post-mortem than the single-stranded nicks that are largely responsible for fragmentation. For this reason, DNA sequences may be present in fossil remains long after negative amplification results are obtained [32,33].

Some methods have been used to revert damages of ancient dna and improve the amplifiable dna templates and sequence reliability. As example, PFU and TAQ hifi, high fidelity polymerase enzymes leading a sequencing with minimal errors [34,35].

Similarly, uracil-n-glycosylase (UNG) takes out deamination products of cytosine and is an important means to determine the origins of sequence variation [31-36]. $n$ phenacylthiazolium bromide (PTB) appears to break intermolecular cross-links caused by advanced glycosylation end products, although the exact mode of operation remains unclear [37].

The actual knowledge about DNA damages only permit partial enzymatic repair treatments for DNA [38].

\section{CONCLUSIONS}

Nucleic acids, oligonucleotides and nucleotides are mainly damaged by mechanisms as chemical degradation by electrophilic reaction, attack of radicals, hydrolytic deamination or oxidative damage caused by ionizing radia- 
tion.

With the actual knowledge about DNA, damages are the only possible partial enzymatic repair treatments.

\section{REFERENCES}

[1] Hofreiter, M., Serre, D. Poinar, H.N. Kuch, M. and Pääbo, S. (2001) Ancient DNA. Nature Reviews Genetics, 2, 353-359. http://dx.doi.org/10.1038/35072071

[2] Peters, K.E. Walters, C.C. and Moldowan, J.M. (2005) The biomarker guide, volume I: Biomarkers and isotopes in the environment and the human history. Cambridge University Press, Cambridge.

[3] Hurley, H.L. (2002) DNA and its associated processes as targets for cancer therapy. Nature Reviews Cancer, 2, 188200. http://dx.doi.org/10.1038/nrc749

[4] Wolkenberg, S.E. and Boger, D.L. (2002) Mechanisms of in situ activation for DNA-targeting antitumor agents. Chemical Reviews, 102, 2477-2496. http://dx.doi.org/10.1021/cr010046q

[5] Remers, A.P. ( 1991) Pharmaceutical chemistry. In: J.O. W.A.R. and Delgado, W.A. Eds., Antineoplastic Agents, Lippincott, Philadelphia, 313.

[6] Lawley, P.D. and Phillips D.H. (1996) DNA adducts from chemotherapeutic agents. Mutation Research, 355, 13-40. http://dx.doi.org/10.1016/0027-5107(96)00020-6

[7] Beranek, D.T. (1990) Distribution of methyl and ethyl adducts following alkylation with monofunctional alkylating agents. Mutation Research, 231, 11-30. http://dx.doi.org/10.1016/0027-5107(90)90173-2

[8] Singer, B. and Grunberger, D. (1983) Molecular biology of mutagens and carcinogens. Plenum, New York. http://dx.doi.org/10.1016/0027-5107(90)90173-2

[9] Moschel, R.C., Hudgins, W.R. and Dipple, A. (1979) Selectivity in nucleoside alkylation and aralkylation in relation to chemical carcinogenesis. The Journal of Organic Chemistry, 44, 3324. http://dx.doi.org/10.1021/jo01333a010

[10] Loechler, E.L. (1994) A Violation of the swain-scott principle, and not SN1 versus Sn2 reaction mechanisms, explains why carcinogenic Alkylating Agents can form different proportions of adducts at oxygen versus nitrogen in DNA. Chemical Research in Toxicology, 7, 277. http://dx.doi.org/10.1021/tx00039a001

[11] Lu, X., Heilman,J. M., Blans, P. and Fishbein, J.C. (2005) The structure of DNA dictates purine atom site selectivity in alkylation by primary diazonium ions. Chemical Research in Toxicology, 18, 1462.

http://dx.doi.org/10.1021/tx0501334

[12] Breen, A.P. and Murphy, J.A. (1995) Reactions of oxyl radicals with DNA. Free Radical Biology \& Medicine, 18, 1033. http://dx.doi.org/10.1016/0891-5849(94)00209-3

[13] Burrows, C.J. and Muller, J.G. (1998) Oxidative nucleobase modifications leading to strand scission. Chemical Reviews, 98, 1109. http://dx.doi.org/10.1021/cr960421s

[14] Scholes, G., Ward, J.F. and Weiss, J. (1960) Mechanism of the radiation-induced degradation of nucleic acids.
Journal of Molecular Biology, 2, 379. http://dx.doi.org/10.1016/S0022-2836(60)80049-6

[15] Gajewski, E., Rao, G., Nackerdien, Z. and DIzdaroglu, M. (1990) Modification of DNA bases in mammalian chromatin by radiation-generated free radicals. Biochemistry, 29, 7876. http://dx.doi.org/10.1021/bi00486a014

[16] Wallace, S.S. (2002) Biological consequences of free radical-damaged DNA bases. Free Radical Biology \& Medicine, 33, 1. http://dx.doi.org/10.1016/S0891-5849(02)00827-4

[17] Dizdaroglu, M. (1994) [1]Chemical determination of oxidative DNA damage by gas chromatography-mass spectrometry. Methods in Enzymology, 234, 3. http://dx.doi.org/10.1016/0076-6879(94)34072-2

[18] Dizdaroglu, M., Jaruga, P., Birincioglu, M. and Rodriguez, H. (2002) Free radical-induced damage to DNA: mechanisms and measurement. Free Radical Biology \& Medicine, 32, 1102. http://dx.doi.org/10.1016/S0891-5849(02)00826-2

[19] Evans, M.D., Dizdaroglu, M. and Cooke, M.S. (2004) Oxidative DNA damage and disease: Induction, repair and significance. Mutation Research, 567, 1. http://dx.doi.org/10.1016/j.mrrev.2003.11.001

[20] Höss, M., Dilling, A., Currant, A. and Pääbo, S. (1996) Molecular phylogeny of the extinct ground sloth Mylodon darwinii. Proceedings of the National Academy of Sciences of the United States of America, 93, 181-185. http://dx.doi.org/10.1073/pnas.93.1.181

[21] Lindahl, T. (1993) Recovery of antediluvian DNA. Nature, 365, 700. http://dx.doi.org/10.1038/365700a0

[22] Dizdaroglu, M. (1992) Oxidative damage to DNA in mammalian chromatin. Mutation Research, 275, 331-342. http://dx.doi.org/10.1016/0921-8734(92)90036-O

[23] Paabo, S. (1989) Ancient DNA: Extraction, characterization, molecular cloning, and enzymatic amplification. Proceedings of the National Academy of Sciences of the United States of America, 86, 1939-1943. http://dx.doi.org/10.1073/pnas.86.6.1939

[24] Dizdaroglu, M., (1991) Chemical determination of free radical-induced damage to DNA. Free Radical Biology \& Medicine, 10, 225-242. http://dx.doi.org/10.1016/0891-5849(91)90080-M

[25] Saiki, R.K., Scharf, S., Faloona, F., Mullis K.B. Horn, G. T., Erlich, H.A. and Arnheim, N. (1985) Enzimatic amplification of betaglobin genomic sequences and restriction analysis for diagnosis of sickle cell Anemia. Science, 230, 1350-1354. http://dx.doi.org/10.1126/science.2999980

[26] Mullis, K.B. and Faloona, F. (1987) Specific synthesis of dna in vitro via a polymerase-catalyzed chain reaction. Methods in Enzymology, 155, 335-350. http://dx.doi.org/10.1016/0076-6879(87)55023-6

[27] Thomas, R.H., Schaffner, W., Wilson, A.C. and Paabo, S. (1989) DNA Phylogeny of the extinct marsupial wolf. Nature, 340, 465-467. http://dx.doi.org/10.1038/340465a0

[28] Cooper, A., Mourer-Chauvire, C., Chambers, G.K., Von Haeseler, A., Wilson, A.C. and Paabo, S. (1992) Inde- 
pendent origins of New Zealand moas and kiwis. Proceedings of the National Academy of Sciences of the United States of America, 89, 8741-8744. http://dx.doi.org/10.1073/pnas.89.18.8741

[29] Sidow, A., Wilson, A.C. and Paabo, S. (1991) Bacterial DNA in clarkia fossils. Philosophical Transactions of the Royal Society B, 333, 429-433. http://dx.doi.org/10.1098/rstb.1991.0093

[30] Richards, M.B., Sykes, B.C., Hedges, R. (1995) Authenticating DNA extracted from ancient skeletal remains. Journal of Archaeological Science, 22, 291-299. http://dx.doi.org/10.1006/jasc.1995.0031

[31] Gilbert, M.T.P., Hansen, A.J., Willerslev, E., Barnes, I., Rudbeck, L., Lynnerup, N. and Cooper, A. (2003) Characterisation of genetic miscoding lesions caused by postmortem damage. The American Journal of Human Genetics, 72, 48-61. http://dx.doi.org/10.1086/345379

[32] Geigl, E.M. (2002) On the circumstances surrounding the preservation and analysis of very old DNA. Archaeometry, 44, 337-342. http://dx.doi.org/10.1111/1475-4754.t01-1-00066

[33] Willerslev, E., Hansen, A.J., Brand, T.B., Rønn, R., Barnes, I., Wiuf, C., Gilichinsky, D.A., Mitchell, D. and Cooper, A. (2004) Long-term persistence of bacterial DNA. Current Biology, 14, R9-R10. http://dx.doi.org/10.1016/j.cub.2003.12.012
[34] Willerslev, E., Hansen, A.J., Christensen, B., Steffensen, J.P. and Arctander, P. (1999) Diversity of holocene life forms in fossil glacier ice. Proceedings of the National Academy of Sciences of the United States of America, 96, 8017-8021. http://dx.doi.org/10.1073/pnas.96.14.8017

[35] Cooper, A., Lalueza-Fox, C., Anderson, S., Rambaut, A., Austin, J. and Ward, R. (2001) Complete mitochondrial genome sequences of two extinct moas clarify ratite evolution. Nature, 409, 704-707. http://dx.doi.org/10.1038/35055536

[36] Hofreiter, M., Jaenicke, V., Serre, S., Von Haeseler, A. and Pääbo, S. (2001) DNA sequences from multiple amplifications reveal artifacts induced by cytosine deamination in ancient DNA. Nucleic Acids Research, 29, 47934799. http://dx.doi.org/10.1093/nar/29.23.4793

[37] Poinar, H.N., Hofreiter, M., Spaulding, G.S., Martin, P.S., Stankiewicz, A.B., Bland, H., Evershed, R.P., Possnert, G. and Pääbo, S. (1998) Molecular coproscopy: Dung and diet of the extinct ground sloth. Nothrotheriops Shastensis. Science, 281, 402-406. http://dx.doi.org/10.1126/science.281.5375.402

[38] Di Bernardo, G., Del Gaudio, S., Cammarota, M., Galderisi, U., Cascino, A. and Cipollaro, M. (2002) Enzymatic repair of selected cross-linked homoduplex molecules enhances nuclear gene rescue from pompeii and herculaneum remains. Nucleic Acids Research, 30, E16. http://dx.doi.org/10.1093/nar/30.4.e16 